Чечель Анна Олександрівна доктор економічних наук, доцент, завідувач кафедри публічного управління та адміністрування, Донецький державний університет управління, вул. Карпінського, 58, м. Маріуполь, 87500, тел.: (0629) 388-29-9, e-mail: annachechel.ac@gmail.com, https://orcid.org/ 0000-0003-4307-5574

Сошенко Даниїл Іванович магістр, кафедра публічного управління та адміністрування, Донецький державний університет управління, вул. Карпінського, 58, м. Маріуполь, 87500, тел.: (0629) 388-29-9, e-mail: daniil.soshenko777@gmail.com, https://orcid.org/0000-0001-6413-8728

\title{
АДМІНІСТРУВАННЯ ПЕРЕРОБКИ ВІДХОДІВ МЕТАЛУРГІЙНОГО ВИРОБНИЦТВА
}

Анотація. Ефективне управління металургійним підприємством передбачає сьогодні досягнення та підтримку балансу соціо-еколого-економічних аспектів іiі діяльності. Тож актуальною $є$ розробка та реалізація будь-яких системних заходів, які би не просто підвищували продуктивність металургійного виробництва як «чистого», тобто маловитратного 3 точки зору використання енергії та ресурсів довкілля, але й робили його екологічно відповідальним на всіх рівнях його організаційної системи. Метою статті $є$ обгрунтування нових організаційно-економічних інструментів для управління процесом переробки відходів металургійного виробництва у вітчизняних умовах. Обгрунтовано, що актуальні інноваційні інструменти для управління промисловими відходами можна будувати на основі таких бізнес-моделей як «фактичний стандарт» або модель «відокремлюючого (підприємницького) типу», або сучасної інтернетплатформи. У будь-якому разі, головною метою таких об'єднань має бути спільне використання можливостей інтернету i реального бізнесу. Розглянуто такі організаційні форми підприємств як електронні біржі вторинної сировини, спільні підприємства або промислові кластери з переробки, які мають в своєму складі транспортні компанії, або використовують транспортні аутсорсингпослуги. Розглянуто можливість застосування в переробному бізнесу такої новітньої форми фінансування як краудфандинг (краудінвестинг), перевагами якого є: 1) охоплення великої кількості зацікавлених осіб; 2) залучення користувачів, які отримують додаткову мотивацію до виконання проекту; 3) отримання великої кількості варіантів досягнення цілі; 4) фіксовані терміни і 
чіткі часові орієнтири.

Ключові слова: металургійне підприємство, промислові відходи, рециклінг відходів, бізнес-моделі, краудінвестинг.

Chechel Anna Oleksandrivna Doctor of Economics, Associate Professor, Head of the Department of Public Administration and Management, Donetsk State University of Management, Karpinskoho St., 58, Mariupol, 87500, tel.: (0629) 388-29-9, e-mail: annachechel.ac@gmail.com,https://orcid.org/0000-0003-4307-5574

Soshenko Danyil Ivanovych Master of Administrative Management, Department of Public Administration, Donetsk State University of Management, Karpinskoho St., 58, Mariupol, 87500, tel.: (0629) 388-29-9, e-mail: daniil.soshenko777@gmail.com, https://orcid.org/0000-0001-6413-8728

\title{
ADMINISTRATION OF METALLURGICAL PRODUCTION WASTE PROCESSING
}

\begin{abstract}
Effective management of a metallurgical enterprise today involves achieving and maintaining a balance of socio-ecological and economic aspects of its activities. Therefore, it is important to develop and implement any systemic measures that would not only increase the productivity of metallurgical production as "clean", low in terms of energy and environmental resources, but also make it environmentally responsible at all levels of its organizational system. The purpose of the article is to substantiate new organizational and economic tools for managing the process of processing waste from metallurgical production in the domestic environment. It is substantiated that the current innovative tools for industrial waste management can be built on the basis of such business models as the "actual standard" or the model of "separating (business) type", or a modern Internet platform. In any case, the main goal of such associations should be to share the opportunities of the Internet and real business. Such organizational forms of enterprises as electronic exchanges of secondary raw materials, joint ventures or industrial clusters for processing, which include transport companies or use transport outsourcing services, are considered. The possibility of using in the processing business such a new form of financing as crowdfunding (crowdfunding), the advantages of which are: 1) coverage of a large number of stakeholders; 2) involvement of users who receive additional motivation to implement the project; 3) obtaining a large number of options for achieving the goal; 4) fixed deadlines and clear time frames.
\end{abstract}

Keywords: metallurgical enterprise, industrial waste, waste recycling, business models, crowdfunding. 
Постановка проблеми. У науковій публікації [1] з журналу «Економічний вісник Донбасу» міститься цікаве порівняння щодо промислових відходів, які утворюються в результаті виробничої діяльності металургійного комбінату «Азовсталь»: «той же комбінат «Азовсталь» за рік утворює майже на $25 \%$ більше промислових відходів, ніж 4-6 млн мешканців Києва утворюють побутових відходів» [1, с. 63]. Це яскраве порівняння вже само по собі говорить про актуальність та гостроту проблеми поводження з відходами для комбінату, міста та регіону в цілому. А про те, що проблема промислових відходів не є локальною, промовисто говорить рейтинг Світового Банку 2017 року - там Україна займає дев'яте місце серед країн, які продукують найбільше відходів на одну особу на рік. Отже, знаходження ефективних інструментів та форм співпраці суб'єктів господарювання щодо переробки промислових відходів $\epsilon$ важливим питанням адміністрування екологічної діяльності металургійних підприємств.

Аналіз досліджень і публікацій. Докладна характеристика відходів металургійного виробництва та їх впливу на екологію території міститься в роботах В.А. Носкова та В.Ф. Макогона [2], Л. І. Крюковської, О. П. Кобзистої,, В. О. Хрутьби [3]. Про можливі форми підприємств 3 переробки промислових відходів, зарубіжний досвід функціонування таких підприємств писали I.M. Кочешкова [1], М.М. Петрушенко [4], Джо Стадвелл [5] та інші фахівці. У дисертаційних та монографічних дослідженнях науковці та експерти презентують доробок, пов'язаний 3 розробкою організаційно-економічного механізму управління рециклінгом відходів в різних сферах господарства. Але, попри існуючу солідну теоретичну базу та практичні розрахунки, пошук ефективних форм створення та функціонування підприємств 3 переробки відходів, особливо промислових, має тривати постійно.

Мета статті - обгрунтувати нові організаційно-економічні інструменти для управління цим процесом у вітчизняних умовах.

Виклад основного матеріалу. Будь-яке металургійне виробництво $\epsilon$ високодиверсифікованим бізнесом, оскільки і в технологічному, і в збутовому, і в обслуговуючому плані підприємству доводиться комунікувати 3 великою кількістю партнерів, вибудовуючи з кожним із них певну модель бізнес-відносин. Такі виробництва, щоб успішно функціонувати першими (i Україна не $є$ винятком) приходять до розуміння використання новаторських підходів в бізнесі, які будуються на визначенні у кого, де і яким чином можна отримувати прибуток, а також як ці канали отримання прибутку захищати. Ряд новаторських підходів до побудови бізнес моделей обгрунтовано в роботі А. Сливотскі та Д. Моррісона «Маркетинг зі швидкістю думки (інноваційні моделі бізнесу)» [6]. Описаний ними тип бізнес-моделі для крупних компаній називається «модель на основі фактичного стандарту». Ланцюжок такої бізнес-моделі може включати: 
отримання відходів в процесі виробництва - переробку відходів 3 метою вилучення або створення нових видів продукції для їх використання в основному виробництві або у інших галузях промисловості. Тут роль фактичного стандарту відіграє отримана 3 відходів продукція, а виробники додаткової продукції та споживачі залучаються до сфери діяльності власника стандарту.

Якщо, за А. Сливотскі та Моррісоном, фактичний стандарт визначає параметри руху потоку інновацій, то зацікавленими особами в металургійному виробництві мають бути власники відходів, які надають ресурс для переробки, тобто «створюють ефект типу «штовхай»), ті, хто 3 відходів отримує нову продукцію (наприклад, шлак для дорожнього будівництва), а також іiі споживачі створюють ефект типу «тягни». Загальний ефект «тягни-штовхай» суттєво прискорює рух потоку продукції, підвищує ефективність каналу.

Наступною інноваційною моделлю бізнесу, придатною для розвитку бізнесу 3 переробки відходів металовиробництва, $\epsilon$ модель «відокремлюючого (підприємницького) типу», яка забезпечує додаткову мотивацію для власників відходів-ресурсів («штовхачів»). У цьому випадку менеджери підприємств 3 переробки відходів одержують власний капітал, прив'язаний до цієї структури. Вони самі відповідають за кінцевий результат, тому можуть закупати відходи у інших власників. Якщо вони працюють добре, їхній капітал зростає швидко i вони ефективно винагороджуються. Але у такому випадку кожному підприємству, що відокремлюється, треба налагодити свою ефективну логістичну систему.

У будь-якому разі і металургійне виробництво, і промисловість в цілому, i будь-яке виробництво взагалі в сучасному світі прагнуть до розвитку не за рахунок створення доданої вартості, а за рахунок співпраці, обміну благами, використання поновлюваних джерел енергії та рівного й вільного для всіх доступу до інформації (тобто до Інтернету).

Саме на цих принципах вже створена i успішно функціонує в Польщі компанія 3 переробки пластикових відходів Recyclix (https:/passivinvest.jimdofree.com/invest-portfolio/recyclix/), залучаючи інвестиції для свого розвитку по всьому світові, поєднавши в собі схеми отримання пасивного доходу та організацію й управління переробкою. Основною метою компанії $\epsilon$ одночасний захист інтересів всіх учасників проекту i грамотне управління бізнесом. «Ми об’єднали досить прості речі - вказують засновники компанії переробку сміття та Інтернет, перетворивши це на інноваційний продукт, який працює» [7]. Кожен зареєстрований користувач, як указується на сайті компанії, автоматично стає не тільки щасливим бізнес-партнером, але і цілком реальним захисником навколишнього середовища. Recyclix використовує тільки екологічно безпечні технології, які не шкодять екосистемі, а діяльність компанії допомагає 
відновити їі.

На рис. 1 представлено принципову схему роботи польської компанії, на якій видно, що вся система є відкритою - це означає, що вона відкрита до отримання інформації про забруднювачів довкілля певним типом відходів (пет-тарою в даному разі), отримує таку інформацію, а також надає іï за запитом переробників (інших бізнес-партнерів). Вона також відкрита для інвесторів, які відстежують, яким чином працюють вкладені ними кошти та вибудовують плани щодо подальших інвестицій та виведення прибутку. Тобто Recyclix являє собою певний інформаційно-інвестиційний хаб, у якому сходяться інтереси всіх стейкхолдерів, які пов'язують свою діяльність з очищенням планети від пластику, вторинним використанням ресурсу та отриманням пасивного прибутку.

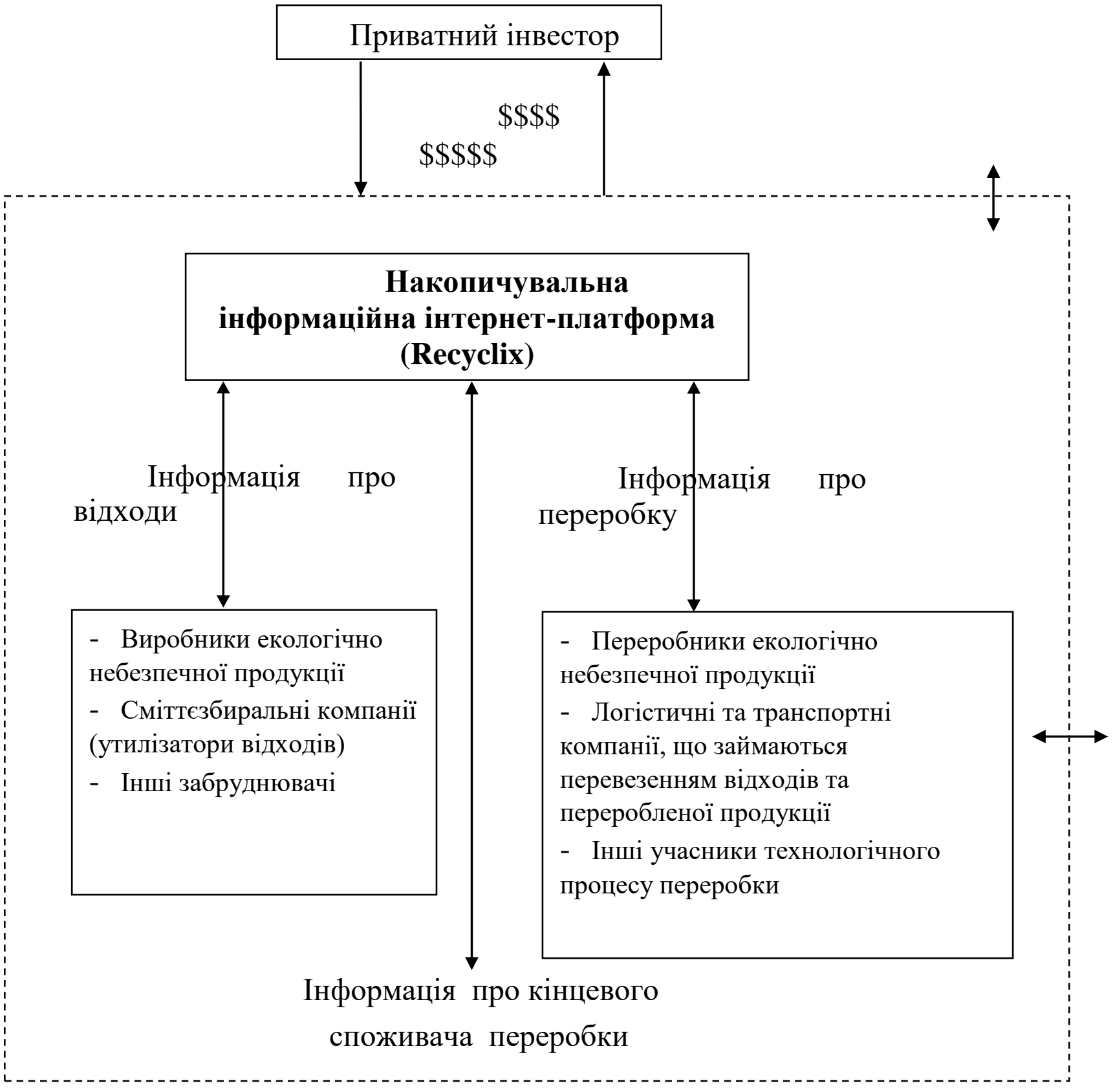

Puc. 1 Схема роботи інтернет-компанії з переробки відходів 
За такою ж схемою можна створювати державні та регіональні агенції 3 переробки відходів, яке б:

- займалося збором інформації про кількість й види промислових відходів і можливості їх переробки або утилізації;

- створило єдину систему організаційно-економічного управління та контролю в галузі переробки промислових відходів;

- надавало інформацію за запитом про компанії, що займаються збором, переробкою та ліквідацією промислових відходів;

- сприяло зацікавленим підприємствам (особам) в обміні промисловими відходами з метою їх використання у виробництві.

На рис. 2 представлено адаптовану під цю ідею принципову схему роботи такої агенції,. де держава виступає як інвестор, а отримуваний від адміністрування переробки дохід спрямовує в інфраструктурні екологічні проекти.

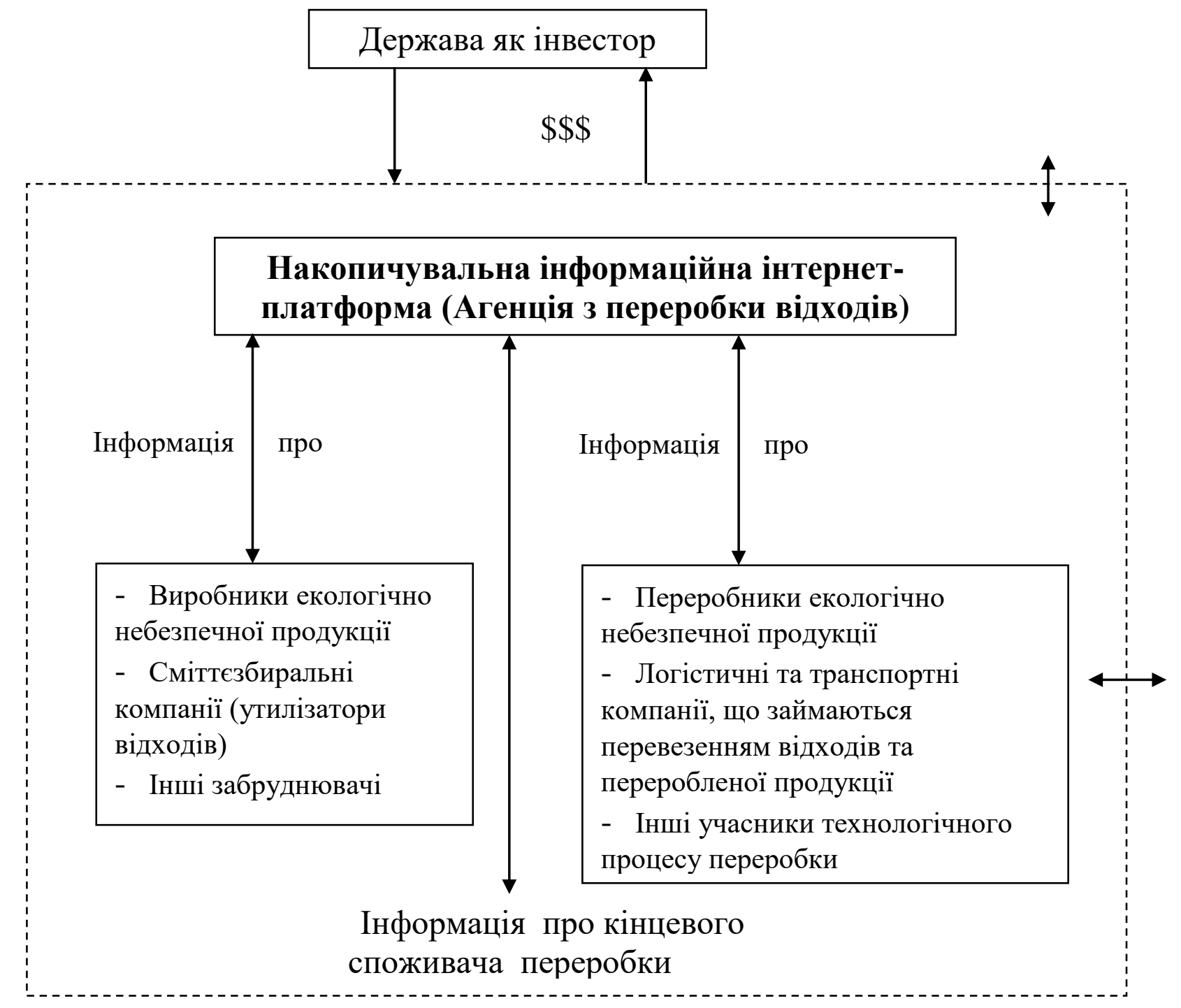

Pис. 2 Схема роботи агенції з переробки відходів з державними інвестиціями (авторська розробка) 
I.M. Кочешкова обгрунтовує, ще й таку, наприклад, організаційну форму для вторинного використання відходів як спільне підприємство власників, переробників та споживачів отриманої з відходів продукції або промисловий кластер [1]. Він міг би об'єднати географічно локалізовані підприємства, які мають відходи, підприємства 3 їх переробки або утилізації та транспортні підприємства, які спеціалізуються на перевезенні відходів. Можливий і варіант, наголошує вона, коли транспортування відходів надається на аутсорсинг. 3 боку держави (центральних та місцевих органів влади) найліпшою формою сприяння буде здійснення пільгової податкової та бюджетної політики.

На рис. 3 показано схему, яким чином можна було би організувати таку співпрацю варіант (а) - транспортна компанія в складі СП, (б) - транспортна компанія на аутсорсингу.

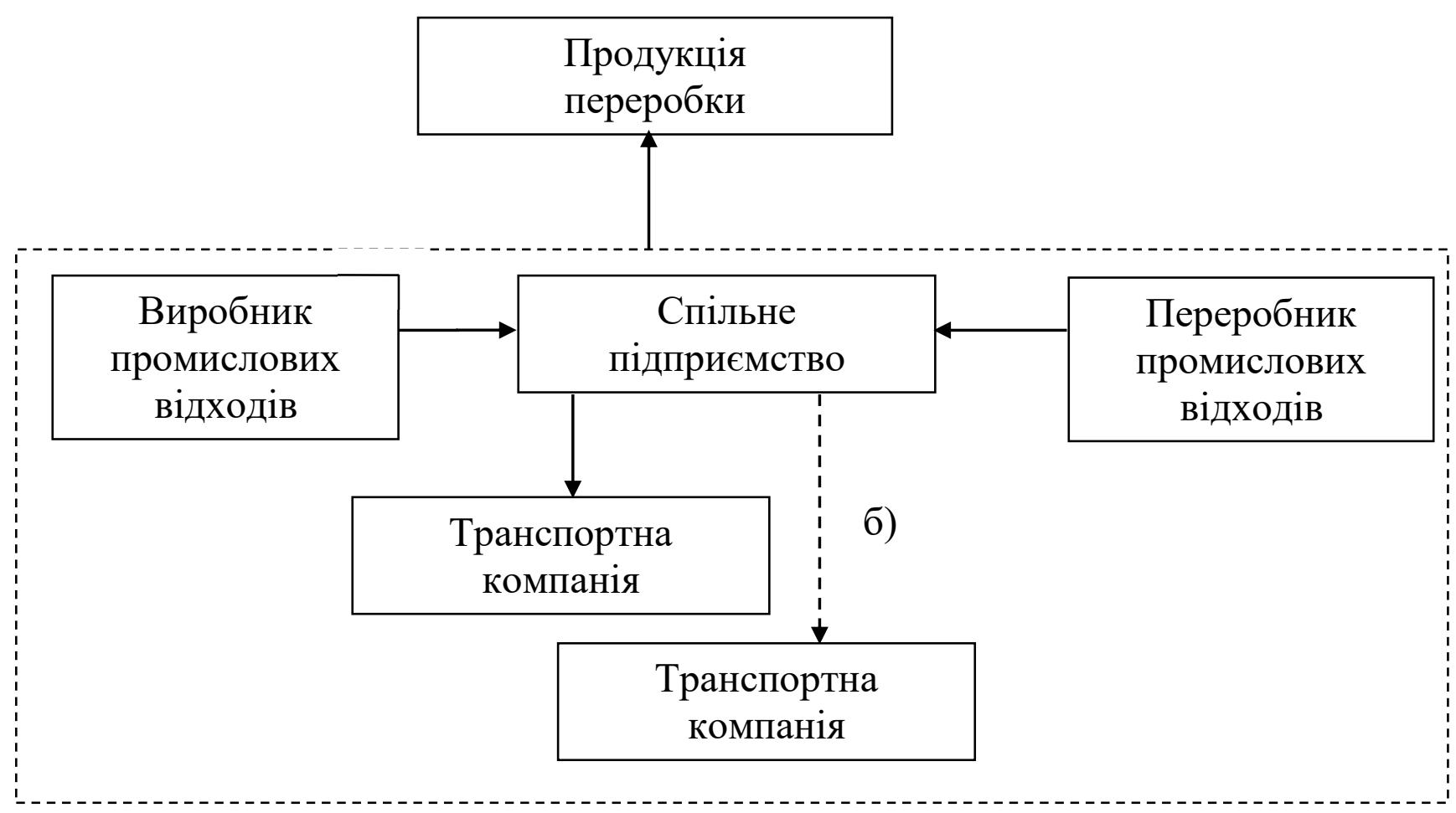

Pис. 3.3 Схема роботи спільного підприємства або промислового кластера з переробки відходів (авторська розробка)

Сьогодні споживачами металургійних шлаків в Україні є вітчизняні виробники цементу: Група компаній CRH, “Дікергофф Цемент Україна", “ХайдельбергЦемент Україна”, “Івано-Франківськ Цемент” та інші. “У цементній галузі утилізується майже $42 \%$ загального обсягу утилізації шлаків в Україні”... I лише $20 \%$ металургійних шлаків на вітчизняних теренах застосовується у дорожньому будівництві (як вторинний щебінь), тоді як у країнах $Є С$ цей показник вдвічі більший — 46\%. Наприклад, такі об'єкти, як траси Маріуполь Запоріжжя, Запоріжжя - Дніпро, Дніпро - Кривий Ріг, автомобільна дорога Р-52 
Дніпро- - Решетилівка збудовані 3 використанням доменних шлаків... Примітно, що сталеплавильний шлак в Україні практично не знаходить застосування в інших галузях... Тим часом європейці застосовують його, наприклад, у якості мінеральних добрив (2,7\%), для гідравлічного інжинірингу $(2,2 \%)$, як забутівку виробленого простору шахт у гірничодобувній та гірничометалургійній галузях (19\%)” [8].

Ще одним реальним прикладом переробки металургійного шлаку $є$ досвід “АрселорМіттал Кривий Ріг” (АМКР). Здебільшого замовниками цієї вторсировини є будівельні та дорожні компанії. Кілька років тому підприємство саме ініціювало використання шлаків для будівництва доріг і на сьогодні вже реалізовано близько 200 тис.т відвального шлаку. Частка утилізації, за підрахунками фахівців комбінату, склала приблизно $13 \%$ річного обсягу утворення шлаків на комбінаті. Щороку АМКР генерує 1,5 млн т відвального шлаку без урахування гранульованого, а загальний обсяг шлаку, що знаходиться у відвалах і хвостосховищах підприємства, складає 55 млн куб.м.

Перспективним для використання $є$ і сталеплавильний шлак, який в Україні сьогодні майже не використовується, а в країнах СС, 46\% від загального обсягу його утилізації використовується в дорожньому будівництві, 2,7\% - додають в мінеральні добрива, 2,2\% - для гідравлічного інжинірингу [9].

За даними експертів GMK - Центру «Шлак широко застосовують у дорожньому будівництві в США, Японії, Бразилії. Він може використовуватися як в основі, так і в несівних шарах автомобільних доріг. У зв’язку з тим, що в Україні велика частина доріг перебуває в критичному аварійному стані, ми бачимо великі перспективи використання шлаку в дорожньому будівництві. Це дасть змогу суттєво знизити не лише витрати на реалізацію інфраструктурних проектів, а й підвищити їх якість, а також поліпшити екологічну ситуацію в країні загалом» [10].

Разом із тим для реалізації подібних ініціатив має бути державна підтримка.

За словами експертів треба врегулювати законодавчу базу, зокрема необхідно змінити нормативну базу 3 екологічного податку, щоб у металургійних комбінатів була можливість його цільового використання на вирішення проблеми застосування шлаків у промисловості, логістиці. Адже для використання цих відходів їх необхідно досліджувати, терикони потрібно розбирати, калібрувати, готувати до вивезення. I кожен етап передбачає придбання відповідної техніки. в усіх розвинених країнах є державні програми із повторного використання відходів метвиробництва. Їх виконання суворо контролюють уряди країн. «Я вважаю, що відходи металургійної промисловості не можуть бути бізнесом. Компанії, які хочуть і можуть переробляти відходи металургії у вигляді доменних гранульованих шлаків, мають отримувати на цю 
діяльність дотації, які стимулюватимуть підприємства, дадуть можливість модернізувати обладнання тощо [8].

Конкуренцію традиційним формам залучення фінансових коштів може створити такий інструмент, як краудфандинг (краудінвестинг). (від англ. crowd «натовп» i funding - «фондування»).

Загальна логіка роботи цього інструменту така:

1) організація (підприємство, компанія) повідомляє про свою проблему i запитує допомоги у експертів з громадськості та бізнес-кіл про способи іiі вирішення;

3) зацікавлені особи та компанії надсилають пропозиції рішень;

4) вони ж колективно разом із представниками організації-запитувача обирають найкраще рішення;

5) запитувач морально або матеріально винагороджує людей, які надіслали найкращі пропозиції ;

6) остаточне рішення приймає організація-запитувач;

7) організація досягає потрібної цілі.

Цей механізм отримання практично безкоштовної допомоги від сторонніх осіб вже давно і успішно використовується в бізнесі та політиці Окрім акумуляції коштів і визначення напрямків витрат, він, за словами авторів роботи [11] здатний змінити свідомість населення саме через можливість отримувати певну фінансову вигоду від їх вкладень. Цей інструмент характеризується більшою гнучкістю у впровадженні проектів; робить можливим швидке виділення коштів (термін збору коштів чітко визначений); забезпечує прозорість інформації щодо проекту, підзвітність і відповідальність перед фаундерами та беккерами; дозволяє не тільки отримувати прибуток підприємствам, але й впроваджувати проекти благоустрою інфраструктури, допомоги певним соціальним категоріям населення тощо; дозволяє знизити трансакційні витрати на організацію фінансування проектів завдяки меншому числу посередників; масово залучає інвесторів, звертаючись не лише до економічних мотивів, а й до спільних соціальних інтересів.

Тобто краудфандинг, а точніше краудінвестинг знімає ряд певних обмежень традиційних способів фінансування. Завдяки інноваційним характеристикам він має перспективи отримати досить скоро статус повноцінного учасника фінансового ринку фінансових, вигравши конкуренцію у банків та інших фінансових посередників.

Але як офіційний фінансовий інструмент краудінвестинг в Україні ще потребує прийняття відповідних забезпечувальних законів - передусім закону про краудфандинг (краудінвестинг); визначення засад управління величезним числом інвесторів; уведення обмеження на обсяг фінансування; необхідності 
розкривати повну інформацію про фаундера, який інвестуватиме проект [1].

Наразі в бізнесі структурування краудінвестингу можливо двома способами: через укладання договорів, які передбачають внесення інвестицій в обмін на частку в прибутку особи, що реалізує проект (договір про розподіл прибутку), або через придбання частки в статутному капіталі юридичної особи - реципієнта інвестицій (через збільшення статутного капіталу або реалізацію казначейських часток/акцій). Можливі й змішані варіанти, коли надання коштів здійснюється на основі договору, який передбачає обов'язок одержувача коштів передати частку в своєму статутному капіталі в майбутньому (наприклад, через опціон або договір конвертованої позики).

Висновки. Таким чином, актуальні інструменти для управління промисловими відходами можна будувати на основі таких бізнес-моделей як «фактичний стандарт» або модель «відокремлюючого (підприємницького) типу», або сучасної інтернет-платформи. У будь-якому разі, головною метою таких об'єднань має бути спільне використання можливостей інтернету і реального бізнесу.

Враховуючи реальний світовий досвід, можна створювати електронні біржі вторинної сировини 3 використанням вже наявної бази даних «Відкрите довкілля».

Найбільш прийнятними організаційними формами для вторинного використання відходів можуть бути спільні підприємства або промислові кластери, які мають в своєму складі транспортні компанії або віддають послуги перевезення відходів та переробленої продукції з відходів на аутсорсинг.

Поряд 3 традиційними джерелами фінансування підприємств 3 переробки відходів можна було б використовувати краудфандинг (краудінвестинг), перевагами якого $є$ : 1) охоплення великої кількості зацікавлених осіб; 2) залучення користувачів, які отримують додаткову мотивацію до виконання проекту; 3) отримання великої кількості варіантів досягнення цілі; 4) фіксовані терміни і чіткі часові орієнтири.

\section{Jimepamypa:}

1. Кочешкова I.M. Можливі форми підприємств 3 переробки промислових відходів і джерела фінансування їх створення та функціонування // Економічний вісник Донбасу. № 3 (57), 2019, с. $63-68$.

2. Носков В. А., Макогон В. Ф. Состояние и перспективы утилизации железосодержащих отходов в металлургическом производстве Украины // Металлургическая и горнорудная промышленность. № 4, 2001, с. 98.

3. Крюковська Л. І., Кобзиста О. П., Хрутьба В. О. Розробка системи управління проектами використання металургійних відходів // Metody obliczeniowe i badawcze w rozwoju pojazdow samochodowych i maszyn roboczych samojezdnych - Zarzadzanie i marketing w 
motoryzacji - SAKON'2009. Politechnika Rzeszowska. Tom XX. (23-26 wrzesnia 2009 r.) Rzeszow. 2009, c. 271-274.

4. Петрушенко М.М. Екологічна конфліктність у сфері поводження з відходами: питання управління та оподаткування // Вісник економічної науки України. № 1, 2019, с. 101-105.

5. Стадвелл Джо. Чому Азії вдалося. Успіхи і невдачі найдинамічнішого регіону світу; пер. 3 англ. Олександра Цехановська. Київ: Наш формат, 2017. 448 с.

6. Сливотски А., Моррисон Д. Маркетинг со скоростью мысли. Москва : ЭКМО-Пресс, 2002. $448 \mathrm{c}$.

7. RECYCLIX (Польша) - переработка пластиковых отходов // Passiv-Invest. URL: https://passiv-invest.jimdofree.com/invest-portfolio/recyclix/ (дата звернення 12.04.2021).

8. Як заробити на промислових відходах // Журнал «Бізнес» 04.02.2020. URL: https://business.ua/uk/yak-zarobiti-na-promislovikh-vidkhodakh (дата звернення 18.04.2021).

9. Statistics 2019. EUROSLAG. URL: https://www.euroslag.com/wpcontent/uploads/2019/01/Statistics-2016.pdf (дата звернення 18.04.2021).

10. GMK Center. Отримання користі: як європейці заробляють на шлаках. URL: https://gmk.center/ua/posts/otrimannya-koristi-yak-ievropejci-zaroblyajut-na-shlakah/ (дата звернення 22.04.2021).

11. Карий O.І., Панас Я.В. Місцеві ініціативи та залучення громадськості до здійснення місцевого самоврядування. Навчальний посібник для посадових осіб місцевого самоврядування/ Асоціація міст України - К.: ТОВ «ПІДПРИСМСТВО «ВІ ЕН ЕЙ», 2015. 176 с.

\section{References:}

1. Kocheshkova, I.M. (2019). Mozhlyvi formy pidpryyemstv $\mathrm{z}$ pererobky promyslovykh vidkhodiv i dzherela finansuvannya yikh stvorennya ta funktsionuvannya [Possible forms of enterprises for processing industrial waste and sources of funding for their creation and operation]. Ekonomichnyy visnyk Donbasu. - Economic Bulletin of Donbass, 3 (57), 63 - 68. [in Ukrainian]

2. Noskov, V. A. \& Makohon, V. F. (2001). Sostoyanye y perspektyvy utylyzatsyy zhelezosoderzhashchykh otkhodov v metallurhycheskom proyzvodstve Ukrayny [State and prospects of utilization of iron-containing waste in metallurgical production of Ukraine]. Metallurhycheskaya $y$ hornorudnay a promyshlennost'. - Metallurgical and mining industry, 4, 98. [in Russian]

3. Kryukovska, L.I. \& Kobzysta, O. P. \& Khrut'ba, V. O. (2009). Rozrobka systemy upravlinnya proektamy vykorystannya metalurhiynykh vidkhodiv [Development of project management system for the use of metallurgical waste]. Metody obliczeniowe $i$ badawcze $w$ rozwoju pojazdow samochodowych $i$ maszyn roboczych samojezdnych - Zarzadzanie i marketing w motoryzacji - SAKON"2009. Politechnika Rzeszowska. XX. (23-26 wrzesnia 2009 r.) Rzeszow, 271-274. [in Ukrainian]

4. Petrushenko, M.M. (2019). Ekolohichna konfliktnist' u sferi povodzhennya z vidkhodamy: pytannya upravlinnya ta opodatkuvannya [Ecological conflict in the field of waste management: management and taxation issues]. Visnyk ekonomichnoyi nauky Ukrayiny. - Bulletin of Economic Science of Ukraine, 1, 101-105 [in Ukrainian].

5. Stadvell, Dzho. (2017). Chomu Aziyi vdalosya. Uspikhy i nevdachi naydynamichnishoho rehionu svitu [Why Asia succeeded. Successes and failures of the most dynamic region of the world]. Kyiv: Nash format [in Ukrainian].

6. Slivotski, A. \& Morrison, D. (2002). Marketing so skorost'yu mysli [Marketing with the speed of thought.]. Moscow: ÉKMO-Press [in Russian]. 
7. RECYCLIX (Poland) - pererabotka plastykovykh otkhodov. Passiv-Invest. Retrieved from https://passiv-invest.jimdofree.com/invest-portfolio/recyclix/ [in Russian].

8. Yak zarobyty na promyslovykh vidkhodakh (04.02.2020). Zhurnal «Biznes» Retrieved from https://business.ua/uk/yak-zarobiti-na-promislovikh-vidkhodakh [in Ukrainian].

9. Statistics 2019. EUROSLAG. Retrieved from https://www.euroslag.com/wp-content/ uploads/2019/01/Statistics-2016.pdf

10. GMK Center. Otrymannya korysti: yak yevropeytsi zaroblyayut' na shlakakh. Retrieved from https://gmk.center/ua/posts/otrimannya-koristi-yak-ievropejci-zaroblyajut-na-shlakah/ [in Ukrainian].

11. Karyy, O.I. \& Panas, Ya.V. (2015). Mistsevi initsiatyvy ta zaluchennya hromads'kosti do zdiysnennya mistsevoho samovryaduvannya. Kyiv: TOV «PIDPRYYEMSTVO «VI EN EY»[in Ukrainian]. 